\title{
Notas para uma hermenêutica psicológica do mistério
}

\author{
Notes for a psychological hermeneutics of the mysterium
}

RESUMO

\begin{abstract}
Este artigo almeja ser mais uma contribuição à discussão do caráter essencialmente hermenêutico da Psicologia da Religião. Apresenta e discute a hipótese central da Psicologia do Profundo, assentada sobre o conceito de inconsciente, como chave hermenêutica fundamental para a desmistificação do mistério inerente à natureza da psique humana e, como passo subsequente e necessário, a religião, enquanto aliada ao processo de remitificação. Isto, porque, em última análise, "o simbólico somente pode ser compreendido adequadamente simbolicamente".
\end{abstract}

Palavras-chave: Hermenêutica, Mistério, Psicologia da Religião, desmistificação, remitificação.

\section{ABSTRACT}

This article aims to be a further contribution to the discussion of the essentially hermeneutical character of Psychology of Religion. It presents and discusses the central hypothesis of the Depth Psychology, based on the concept of the unconscious, as the fundamental hermeneutical key for the demystification of the mystery inherent in the nature of the human psyche and, as a subsequent and necessary step, religion, as an important ally to the process of remythification. This is the case, at least, as "the symbolic can only be adequately understood symbolically".

Keywords: Hermeneutics, Mysterium, Psychology of Religion, demystification, remythification.

\section{Introdução}

O que é psicologia da religião? É a hermenêutica psicológica da religião! Têm-se, assim, três conceitos elementares que constituem o fundamento desta disciplina acadêmica centenária que tem tido seu lugar como subárea da psicologia, da teologia e da ciência da religião. A

1 Professor Associado da Universidade Federal de Juiz de Fora, atuando nos Programas de Pós-graduação em Ciência da Religião e em Filosofia, pesquisando e lecionando especialmente na área de Psicologia da Religião. Contato: sidnei.noe@ufff.edu.br. Submentido em 20/04/2018; aceito em 08/04/2019. 
partir da conceituação de cada um destes elementos é possível sistematizar sua área de abrangência, respectivamente, seus contornos epistemo- metodológicos.

Primeiramente, e em síntese, a Psicologia da Religião tem o seu lugar específico como subárea da Psicologia, pois é o estudo de um comportamento humano especial, distinto, sui generis, porque este vem a ocupar uma posição de fundamento das afecções, intelecções e conações, qual seja o religioso. Isto é, aquele comportamento que é intuído, sentido, constituído, transformado, convertido, metamorfoseado, conflituoso, ajustado, embasado, substanciado, refletido e que leva a uma forma de agir correspondente e característica, a partir da relação que o ser humano afirma ter em relação ao transcendente, sagrado, divino, suprahumano, não obstante à diversidade das denominações religiosas e se sua existência real, em termos científicos válidos atualmente, possa ou não ser confirmada, e que confere sentido último à existência. Caso este não fosse um comportamento singular, como sugerem alguns autores², mal se justificaria a demarcação de uma área específica dentro da Psicologia que se ocupasse de maneira exclusiva deste estudo.

Já na área da Teologia, a Psicologia da Religião tem seu lugar no âmbito da Teologia Prática, teórico-prática, como fronteira de intersecção entre teorias psicológicas e teológicas da religião, no que concerne ao comportamento religioso humano. Como tal, ela assume os contornos de uma ciência dialogal, que busca pelos encontros e desencontros ${ }^{3}$ entre estas duas formas distintas, porém, capazes de estabelecer um diálogo crítico e respeitoso entre si, quiçá complementares, de se falar do ser humano, a religiosa e a psicológica. Obviamente também possui uma "enteléquia» prática propriamente dita; esta, todavia, deve ser concebida menos como uma fusão entre estas duas maneiras distintas de compreender o ser humano, sob a forma de aplicação dos conhecimentos de uma área dentro da outra ${ }^{4}$, e mais, como tarefa inexorável de fomento deste diálogo profícuo e crítico, conforme a crítica de alguns autores psicológicos da psicologia da religião e a reivindicação de alguns teólogos que se ocupam com esta subárea do estudo da Teologia. ${ }^{5}$

E, finalmente, ao longo da história e em diferentes países, o locus da Psicologia da Religião foi sediado no âmbito da Ciência da Religião - e este nos interessa especialmente aqui - onde esta disciplina foi cunhada essencialmente pelo seu caráter "hermenêutico».6 Ainda que, ao situar-se nas outras áreas anteriormente assinaladas, a Psicologia da Religião também não possa esquivar-se da questão hermenêutica ${ }^{7}$ - isto é, aquela atitude que reflete sobre os pressupostos das possibilidades e limites de seu próprio compreender e, por conseguinte,

\footnotetext{
2 "Além disso, nunca se demonstrou que a natureza de qualquer pensamento, sentimento ou emoção de índole religiosa fosse diversa da natureza de qualquer cognição ou afeto". Cf. G. PAIVA, Teorias contemporâneas da Psicologia da Religião, p. 348.

3 Cf. S. V. NOÉ, Encontros e desencontros da Psicologia com a Teologia no estudo da Religião, pp. 154-170.

$4 \mathrm{~J}$. A. van BELZEN categoriza este tipo de recurso à psicologia como "Ancilla, a Psicologia da Religião a serviço do religioso". Cf. IDEM, Constituição histórica da Psicologia Científica da Religião, p. 322s.

5 Para uma compreensão da Teologia Prática, respectivamente, da "Seelsorge" (poimênica), a área equivalente a Psicologia da Religião na Teologia, ainda serve de referência a obra de D. RÖSSLER, Grundriß der Praktischen Theologie, 1993.

6 "Com essa base, a psicologia da religião segue um enfoque de pensamento hermenêutico. Por conseguinte, ela inclui em suas considerações a reflexão sobre os pressupostos de seu próprio raciocínio". Cf. H.-J. FRAAS, $A$ religiosidade humana, p. 10 s.

7 "Equivale dizer que a Psicologia da Religião é uma ciência hermenêutica...". Cf. J. v. BELZEN, op. cit., p. 327. "Em todo o caso, um procedimento que vá além do mero "retratar", ou seja, a formação de uma teoria no verdadeiro sentido pressupõe determinadas premissas cosmovisivas. Não ter consciência delas, em atitude de pretensa objetividade, constitui o verdadeiro perigo metodológico. Também conhecimentos psicológicos empíricos dependem, em princípio, de conceitos ontológicos fundamentais". Cf. H.-J. FRAAS, op. cit., p. 26.
} 
segue os parâmetros do círculo hermenêutico ${ }^{8}$ em suas investigações - é na Ciência da Religião9 que esta disciplina assume um viés essencialmente hermenêutico. Isto, porque o comportamento humano religioso, aliás, como qualquer outro, está fundamentalmente imbricado na psique; ou seja, aquilo que, em suma, é o objeto de estudo da ciência psicológica da religião é, simultaneamente, responsável pela sua interpretação e reflete sobre suas próprias condições e limites de efetuá-la. Em suma, a própria hermenêutica psicológica já é religiosa, haja vista alicerçar-se sobre crenças a respeito de si mesmo, do mundo e daquilo que não se encontra "visível», aos "olhos» dos sentidos, no mundo "invisível» aos sentidos. Ou como diria, de maneira tão sublime, o poeta e filósofo Paul VALÉRY:

O que seríamos nós sem o socorro daquilo que não existe? Pouca coisa, e nossos espíritos desocupados se desfaleceriam se as fábulas, as abstrações, as crenças, os monstros, as hipóteses e os pretensos problemas metafísicos não preenchessem com seres e imagens sem objetos nossas profundezas e nossas trevas naturais. Os mitos são as almas de nossas ações e de nossos amores. Só podemos agir movendonos em direção a um fantasma. Só podemos amar aquilo que criamos. ${ }^{10}$

\section{Hermenêutica}

A discussão do conceito de hermenêutica começa na Antiguidade e se estende até os nossos dias, destacando aspectos constitutivos da arte da interpretação, em diferentes abordagens, em suas respectivas épocas e lugares, até chegar à compreensão universal hodierna de que a própria vida está sob seu domínio. Isto é, viver é hermenêutica! Ou melhor, viver é um constante ato hermenêutico! Neste sentido, nada há, por conseguinte, que possa alijar-se da necessidade interpretativa. E esta, em última instância, remete-nos à própria linguagem, enquanto recurso semântico que permite seu exercício:

Com muito acerto observa Ernildo Stein, (1996, p.76), que: "[t]odos os elementos centrais da hermenêutica filosófica, como a ideia do pré-conceito, a ideia do horizonte, a ideia da história efetual" - (ou efeitual, considerada em sua eficácia ou efetividade) -, "a ideia da consciência histórica," e "a ideia de situação hermenêutica (...) entram em questão quando se procura explicar esta totalidade da linguagem que nos envolve e quando nos queremos apropriar dessa totalidade pela interpretação." A linguagem é, assim, nossa constituição fundamental, razão porque pode Gadamer afirmar que "o ser que pode ser compreendido é linguagem."

E aqui não só se subentende a linguagem falada e escrita, mas também a própria capacidade, maior ou menor, ou até inexistente, de operar o processo cognitivo de metamorfosear toda a sorte de experiências, sensoriais, intuitivas, pulsionais, emocionais, comportamentais, muitas destas, inclusive, inefáveis, em uma forma de representação que faça sentido para si próprio e para os outros. É preciso, por assim dizer, reaprender a se

\footnotetext{
8 "Na esfera interpessoal, a identificação, o uso do nome, a empatia com o outro, sofrer com ele, colocar-se na situação dele, inserir-se compreensivamente no círculo hermenêutico constituem elementos comportamentais básicos e necessários. A criatividade, a utopia, a capacidade de imaginação antecipadora, a projeção encontram-se no mesmo contexto. A escola psicanalítica designa isso de 'narcisismo configurado' (Heinz Kohut)". Cf. H.-J. FRAAS, op. cit., p. 108.

9 Cf. L. H. DREHER, A(s) Ciência(s) da Religião no Brasil: afirmação de uma área acadêmica, pp. 151-178.

10 Cf.P. VALÉRY, Pequena carta sobre os mitos, p. 21.

"Cf. J. GRONDIN, Introdução à hermenêutica filosófica, p. 14s.
} 
surpreender, com Antony T. BOYSEN: “WOw, THERE is a real Living Human Document!'2, seja ele absconso à letra, ou explícito, na experiência vis-à-vis.

Todavia, é fundamental distinguir diferentes variáveis que estão em jogo no processo hermenêutico. A começar pela Geschichtlichkeit (historicidade), ou seja, pelo pano de fundo contextual, histórico-cultural, aquilo que os exegetas bíblicos houveram por bem chamar de Sitz im Leben (lugar vivencial). Esta historicidade molda o frame of reference (moldura sóciocultural-histórica de referência), tanto do autor de um texto ou de uma fala, quanto do seu intérprete, que tenta entender e explicá-lo, como também, do leitor ou ouvinte que procura compreendê-lo. A discussão hermenêutica nos abriu os olhos para o fato de que é ingênua a noção de que estes horizontes são perfeitamente intercambiáveis e não incidem sobre a interpretação e a compreensão. Trata-se de transpor àquilo que Gotthold Ephraim LESSING chamava de uma "vala, larga e horrenda" ("ein garstiger, breiter Graben"ß) e que separa estes diferentes loci no diálogo hermenêutico, ainda que sejam todos contemporâneos entre si. Vale a máxima de Daniel Friedrich Ernst SCHLEIERMACHER que propôs ser o "mal-entendido"14, o ponto de partida para qualquer espiral hermenêutica.

Ainda que a percepção de que o pensar, o sentir e o agir estejam sujeitos à sua imbricação histórico-cultural, como bem o demonstra Philippe ARIĖS15, sua exploração até as últimas consequências é um beco sem saída e isso é acentuado por Eugen DREWERMANN, em sua crítica ao Método Histórico-Críticol6, pela autoevidente razão de que ela mesma é condicionada pelas variáveis hermenêuticas, entre elas, e em especial, a sua própria historicidade. Em outras palavras, o próprio critério da historicidade é histórico. Por outro lado, a consciência deste fato, ao menos, deve suscitar a dúvida a respeito da nossa capacidade compreensiva, até mesmo daqueles textos e falas que nos são contemporâneos: Será que a partir destas três variáveis psíquicas, a intelecção, a afecção e a conação, é possível situar-se no mesmo horizonte, quiçá, fundir-se àquele(a) ou àquilo que buscamos compreender?17

Desde quando começou a indagação sobre as possibilidades interpretativas de "passagens obscuras"18 da Sagrada Escritura, passando pela percepção de que trechos completos, livros inteiros e, até mesmo, o seu texto como um todo estabelecem um enigma a ser decifrado, um longo caminho foi percorrido. Suscintamente este caminho trilhou a ênfase literal, alegórica, a "empatia» com o autor, respectivamente, com seu gênio interior, sua historicidade, concentrando, então, a atenção sobre o leitor ou ouvinte, seus pré-conceitos e pressupostos, sua contextualidade, sua existencialidade, sua capacidade de recepção, para então chegar à

${ }_{12}$ Cf. C. V. GERKIN, The living human document: Re-visioning pastoral counseling in a hermeneutical mode, $219 \mathrm{pp}$.

13 G. E. LESSING, Über den Beweis des Geistes und der Kraft, pp. 31 ss. Interessante é constar que Graben, na língua alemã, tem também o sentido de "cova"!

14 Cf. J. GRONDIN, Introdução à hermenêutica filosófica, p. 123ss.

15 "A história é para mim o sentimento de uma tradição que vive (...). Atualmente, esta história é ainda mais necessária (...). Tendo desaparecido muitas tradições, (...) a história permite tomar plena consciência do que foi vivido espontaneamente outrora e, no final das contas, inconscientemente." P. ARIĖS, O tempo da história, p. 13.

16 "Só que um método absurdo de interpretação, na esteira da exegese histórico-crítica e à sombra da dogmática católica, nem permite construir em cima da constatação feita pela honestidade histórica de que a Bíblia fala em imagens, para desenvolver uma psicologia aprofundada, assim também ampliando a possibilidade de compreensão do ser humano". Cf. E. DREWERMANN, Religião para quê?, p. 147.

17 "No consenso ou 'fusão de horizontes', assim alcançado, exprime-se, então, toda uma nova maneira de compreender, que não representa já, apenas, a verdade de um ou de outro, mas pelo contrário, uma síntese sempre aberta a novas glosas e comentários, ou por outras palavras, a coisa, que é comum a ambos." Cf. L. P. F. da SILVA, Da "fusão de horizontes ao conflito de interpretações... p. 140. Cf. tb. H,- G. GADAMER, Verdade e Método, 736 pp.

${ }^{18}$ Cf. J. GRONDIN, Introdução à hermenêutica filosófica, p 73. 
problemática da linguagem que se interpõe a ambos e que culminou no mote clássico, sentenciado por Hans-Georg GADAMER, já referido antes, de que "o ser que pode ser compreendido é linguagem"19, para finalmente, retomar a interioridade, a profundidade, a inconsciência, a subjetividade que subjaz e interliga todas estas particularidades, de certa forma já antecipada por AGOSTINHO de Hipona, em sua proposição do "verbum interius".

\begin{abstract}
Agostinho não só criou a teoria hermenêutica reconhecidamente mais eficaz do mundo antigo, ele elaborou da maneira mais subtil o significado básico do Logos. Ele recorreu, para isso, à distinção estoica entre uma palavra interior e outra exterior, mas pôde mostrar que o "verbum interius" inabita (sic!) muito bem o Logos exteriorizado. No Verbo divino até foi possível falar de uma igualdade essencial de ambos. Para nós humanos, ao contrário, esta equiparação não será sempre possivel, razão pela qual se faz necessária uma relação hermenêutica com a palavra expressada, para situá-la em seu horizonte adequado. $O$ expressado não se identifica plenamente com o pensado e tencionado, embora queira ser apenas sua corporificação. ${ }^{20}$
\end{abstract}

Todos estes elementos agregados constituem uma série de variáveis a ser considerada, quando se pretende fazer qualquer ciência' ${ }^{21}$, em especial, ciência do espírito (Geisteswissenschaft, como as ciências humanas são designadas no ambiente tudesco, ao menos desde Wilhelm DILTHEY22] e, mais distintamente, uma hermenêutica "psicológica" da religião. Talvez até, não obstante essa longa história, a mesma ainda se encontre em uma fase gestacional e, embora esteja longe de se estabelecer enquanto um "paradigma" 23 próprio, a discussão hermenêutica tenha se constituído como uma epistemologia e metodologia genuína e peculiar às ciências do espírito. ${ }^{24}$ Ainda mais relevante se torna a necessidade de considerar estes aspectos escavados pela hermenêutica, quando se chega à consciência de que não são somente alguns aspectos secundários ou periféricos relativos à vida humana que são "obscuros", mas que o próprio fundamento da vida está absorto em um nimbo de mistério. É, pois, como se o mistério que subjaz à vida humana dissesse, tal qual a Esfinge, udecifra-me ou devoro-te». E qual introspecção humana ousa adentrar mais a fundo estes porões da própria vida, apropriadamente amparada simbolicamente contra a loucura, se não a própria religiosidade?

Portanto, ao invés de falarmos de hermenêutica psicológica da religião, temos que falar em hermenêutica psicológica do mistério, de hermenêutica das experiências limítrofes do ser humano, constituídas e interpretadas religiosamente; isto é, ir a busca das suas razões últimas, situadas em um pântano sombrio, "nas vertiginosas profundidades de nosso íntimo" (Arthur

\footnotetext{
${ }^{19}$ Cf. J. GRONDIN, Introdução à hermenêutica filosófica, p. 15.

20 Cf. J. GRONDIN, Introdução à hermenêutica filosófica, p. 92. Da mesma fonte se nutrem as compreensões basilares de hermenêutica de M. Heidegger e de H.-G. Gadamer. Cf. IDEM, ibidem, p. 19. Cf. tb. R. PALMER, Hermenêutica, 284 pp.

21 "(...) o sentido de "ciência" que vale, ainda hoje, para nós, estudiosos da religião. Trata-se de um conhecimento e de um discurso regrado e coerente, que explicita seus pressupostos e que controla e justifica seus procedimentos, e se aplica, em vários níveis de aproximação, a um fato, experiência ou realidade cultural/espiritual específicos, ou seja, à religião que se manifesta de forma plural na história por meio de vários tipos e apresentando uma estrutura fundamental." Cf. H. L. DREHER, Ciência(s) da Religião..., p. 163. Cf. tb.: "o termo "ciência" nesse sentido de ciência da religião não provém, por exemplo, do positivismo de Comte, mas antes do idealismo crítico (Kant, Schleiermacher) e especulativo (Hegel, Schelling) e da fenomenologia husserliana." IDEM, Ibidem, p. 163 (nota 8).

22 Cf. W. DILTHEY, Einleitung in die Geisteswissenschaften, 1883.

23 Cf. T. S. KUHN, As estruturas das revoluçôes cientificas, 218 pp.

${ }^{24}$ Cf. a clássica proposição de W. DILTHEY, Ideias acerca de uma psicologia descritiva e analítica, 2008.
} 
SCHOPENHAUER)25, muito além das capacidades compreensivas conscientes. É, neste sentido, tarefa genuína da Psicologia da Religião, enquanto ciência humana hermenêutica, adentrar e explorar esta dimensão obscura da existência humana, condensada em sua interpretação religiosa, abscôndita empós suas formas de manifestação através da linguagem falada ou escrita, quiçá conscientes. Este lado misterioso, ainda não-revelado, quer, por sua própria natureza, vir à luz, desvelar-se, manifestar-se, para que o ser humano, justamente face à experiência limítrofe de sua existência, conheça a si mesmo, no sentido de conferir um sentido plausível à sua vida.

Portanto, não é na superfície, no evidente, no que se mostra, no manifesto, no "phainesthai» (a raiz grega de "fenômeno"), que encontramos aquilo que (co)move as pessoas religiosamente. É no subterrâneo, nas fronteiras abissais de seu ser que a coisa lo Es de Sigmund FREUD] se situa; embora, naturalmente, deva admitir-se que esta pode ser "conjurada", e muitas vezes o é, por fatores "exteriores». Está além da forma e do conteúdo, do certo e do errado, do bem e do mal e ao revelar-se de maneira efêmera às pessoas, em suas experiências limítrofes de vida, aparece de forma atrofiada, desfigurada, bizarra, deficiente e limitada, através de relatos falados e escritos. Isso impõe à Psicologia (Hermenêutica) da Religião uma tarefa "arqueológica», quiçá "paleontológica», pois ela terá que abrir um caminho até este nível mais profundo, em meio ao entulho de lugares-comuns, de falas estereotipadas, de nivelamentos morais, dogmáticos e de "sujeições» ao Zeitgeist (espírito da época). Como afirmara Carl Gustav JUNG, é necessário adentrar ao "espírito da profundeza".26 E é precisamente este o caminho a ser percorrido, uma vez que o acesso direto é vedado ao hermeneuta por «espadas de fogo». Significa, pois, que o primeiro passo hermenêutico, a ser necessariamente dado, é essa prospecção daquilo que desfiguradamente pode se tornar manifesto, abrindo caminho em direção ao inefável.

Deduz-se do que foi dito até aqui, que os modelos hermenêuticos capazes de auxiliar nesta empreitada de escavação da interioridade, sob a exterioridade, são limitados. Embora os acessos a estas camadas subterrâneas da vivência religiosa possam ser preparados por pressupostos hermenêuticos excêntricos, como os psicossociológicos, os comportamentais27, enfim, todos aqueles que atribuem ao meio à prerrogativa de modelar a experiência religiosa, é nos modelos que enfatizam o caráter sui generis da vivência, particular, subjetiva, efêmera, intuída, religiosa, que encontramos um caminho para a busca de sua compreensão. E este paradigma já foi posto desde as próprias origens deste escrutínio da alma inaugurado por William JAMES28, Rudolf OTTO29 e outros, através da ciência psicológica da religião, cujos antecessores mais remotos podem ser encontrados na própria Bíblia Sagrada, entre os assim chamados, "livros sapienciais", nos Salmos, no proeminente "hermeneuta» do Cristianismo, o apóstolo Paulo (caso contrário, como compreender a célebre passagem da Carta aos Romanos 7.15, 19: "Não faço o que prefiro, e sim o que detesto"; "Não faço o bem que prefiro, mas o mal que não quero"), na filosofia grega (especialmente no Fedro de PLATÃO30) e em AGOSTINHO de Hipona (Confissõesl), no Pietismo (por exemplo, na obra de Phillip Jacob

25 Cf. A. SCHOPENHAUER, O livre arbitrio, p. 174.

26 "Viste que todas as tuas profundezas estão cheias de loucura?" C. G. JUNG, O livro Vermelho, p. 308. Em outra passagem: "A graça que me aconteceu deu-me fé, esperança e ousadia suficiente para não continuar resistindo ao espírito da profundeza, mas falar suas palavras." IDEM, O livro Vermelho, p. 308. Cf. tb. F. L. M. de SOUZA, O livro vermelho de Jung..., 2015.

27 "As ciências sociais são, no contexto deste conceito de ciência, disciplinas auxiliares da ciência da religião, que é uma disciplina das ciências do espírito ou humanas, se se preferir." Cf. H. L. DREHER, Ciência(s) da Religião..., p. 164.

28 Cf. W. JAMES [1902], As variedades da experiência religiosa, 2015.

29 Cf. R. OTTO, O sagrado.... 224 pp.

30 Cf. PLATÃO, Fedro, 2011.

${ }^{31}$ Cf. AGOSTINHO, Confissões..., 2017. 
SPENER, Pia Desideria32) e, por conseguinte, em Friedrich Daniel Ernst SCHLEIERMACHER (Über die Religion33).34

Entre estes caminhos estão aqueles que dão ênfase à compreensividade, ainda que não se devam descartar definitivamente àqueles que privilegiam a sua descrição funcional - porém, situando-os devidamente como uma atividade exploratória inicial, adicional ou ilustrativa - é que podemos encontrar as pré-condições mais favoráveis. Entendam-se estes, enquanto os que se orientam na fragilidade, no sentimento de incompletude, no déficit ontológico experienciado pelo ser humano e que, em relação ao qual este reage com angústia difusa e medos localizados. É este o poço mais profundo a ser escavado para ir à busca das águas cristalinas de uma vida plena, sem sequelas, doenças e, se possível, eterna, algo ansiado pelas pessoas em todos os tempos e lugares, através da religião, se bem que, também, em outras coisas, que, todavia, e muitas vezes, se demonstram como estéreis e fúteis e que, com certo grau de realismo, jamais serão encontradas plenamente, ao menos, em vida.

Diante deste quadro de aplicação do grande filtro da exploração do "Mistério" na alma humana, o universo de referenciais hermenêuticos de caráter psicológico precisa ser reorientado telescopicamente. Historicamente são aquelas hermenêuticas que postulam a existência, na profundidade do ser, de um lado sombrio da alma, que determina fundamentalmente a vida humana, e cuja estratégia arqueológica é fazer com que este se manifeste; isto é, se revele; ou seja, aquelas que se convencionou chamar de "Psicologias do Profundo"35. E, também, aquelas hermenêuticas, que em parte estão fundadas nas primeiras, e que pretendem interpretar a vida psíquica humana a partir do conceito de Selbst, Self ou ainda, si-mesmo36. Ambas podem assumir o caráter de hermenêuticas remitologizantes e/ou demitologizantes e/ou de hermenêuticas compreensivas e hermenêuticas descritivas ou explicativas, como tão paradigmaticamente propôs Wilhelm DILTHEY.37

\subsection{Hermenêutica psicológica}

Para ser possível uma hermenêutica psicológica da religião é preciso perguntar inicialmente se todas as interpretações psicológicas podem ser consideradas hermenêuticas. Definitivamente, não! Deveriam ser, mas nem sempre o são! «Hermenêuticas» podem ser consideradas somente aquelas que se questionam em relação aos seus próprios pressupostos interpretativos (e dentre

\footnotetext{
32 P. J. SPENER, Pia desideria, 2005.

33 Friedrich D. F. SCHLEIERMACHER, Sobre a religião..., 2000.

34 Para uma visão mais abrangente, confira: H.-J. FRAAS, A Religiosidade Humana, p. 13-24.

35 Também denominada de psicologia profunda, essa corrente psicológica possui diversos matizes, desde a Psicanálise que remonta a S. FREUD, a Psicologia Analítica, de C. G. JUNG ou a Psicologia Individual de A. ADLER, bem como, todas as derivações posteriores. Essas se caracterizam por terem como núcleo comum e fundamental a proposição do conceito de inconsciente: "a corrente que se denomina em sentido amplo 'psicologia profunda', a fim de não a reduzir unicamente à psicanálise freudiana, tem como denominador comum defender a existência de uma dimensão inconsciente na personalidade, à qual se dá um papel primordial em sua dinâmica." Cf. A. ÁVILA, Para conhecer a psicologia da religião, p. 31. Também podem ser incluídas entre estas as releituras, como p. ex., "a teoria das relações objetais, na versão winnicottiana" (cf. G. PAIVA, Teorias contemporâneas da psicologia da religião, p. 348).

36 Neste contexto se inserem compreensões que, de um lado, se remetem a um processo profundamente interior (como por exemplo, em C. G. JUNG. Cf. IDEM, Aion - Estudo Sobre o Simbolismo do Si-mesmo, 2011; M. STEIN, O mapa da alma, 2006); enquanto que de outro, aquelas que destacam a prerrogativa social intrinsecamente associada, como por exemplo, as recentes teorias do "Self Dialógico" (H. J. M. HERMANS e H. J. G. KEMPEN. In: J. A. van BELZEN, Cultura, Religião e Self-Dialógico..., pp. 30-52).

37 Cf. W. DILTHEY, Ideen über eine beschreibende und zergliedernde Psychologie, 1894; W. DILTHEY, Ideias acerca de uma psicologia descritiva e analítica, 2008; IDEM, O surgimento da hermenêutica, p. 11-32.
} 
estes, especialmente, os antropológicos e cosmovisivos ${ }^{38}$ ) e que, portanto, com certa autocrítica e humildade, absolutamente indispensável a toda e qualquer atividade acadêmica, reconhecem a relatividade e a parcialidade de suas próprias premissas e asserções e as assumem conscientemente. Em outras palavras, "hermenêuticas» são aquelas interpretações que não absolutizam suas pré-compreensões para, em favor de um diálogo profícuo, sob a forma de um evento, de um acontecimento, de um encontro, de um diálogo crítico, transformarem e se deixarem transformar pelo processo de busca da compreensão.

\subsection{0 inconsciente como hipótese hermenêutica}

A inferência da existência de um lado impreciso, difuso, velado, na alma começa a ganhar contornos nas petites perceptiones ("pequenas percepções") de Gottfried Wilhelm LEIBNIZ. Da miríade de impressões sensoriais, o ser humano somente seria capaz de se concentrar em algumas específicas a cada vez, remanescendo as demais em um limbo nebuloso, variando em grau de intensidade e extensão. Certamente qualquer uma das demais, ou mesmo um conjunto delas, poderia vir a ocupar o arcano da consciência, bastando para isto que algum evento fortuito dirigisse a atenção da mesma àquelas.39

Desde então, especialmente na época denominada grosso modo de Romantismo, e em especial, em sua variante teuta, esta especulação em torno da hipótese da existência de uma dimensão extrínseca à consciência, ganhou força. Tanta, que se passou à ideia de que esta, inclusive, fosse a mais elementar ao psiquismo humano. Que a consciência racional, aquela tão drasticamente dimensionada por René DESCARTES, no seu mote, cogito, ergo sum 40 ("penso, portanto sou"), não passaria de um mero facho de luz em meio a um oceano abissal e sem fronteiras de trevas. Esta "verdadeira África interior" (Jean PAUL41) seria tão determinante para a vida humana que não poderia nem deveria ser ignorada. Ao contrário, deveria ser explorada, trazida à luz, para enriquecer a vida consciente. Assim, Carl Gustav CARUS pode postular o aforismo: "o inconsciente é a chave (hermenêutica) para o consciente!"42

Poetas como NOVALIS43, Jean PAUL44, Johann Christian Friedrich HÖLDERLIN 45 e, inclusive, Johann Wolfgang von GOETHE46, exploraram e trouxeram à tona a ambivalência característica destas profundezas da alma humana, marcada por humores de natureza contraditória. De um lado a nobreza, a bondade, a largueza e a mansidão do espírito e de outro, a agressividade, a destrutividade, a ipseidade, a incomunicabilidade e a melancolia profunda. A via de acesso a estes recônditos da alma humana, sob este viés Romântico, se dá pela genialidade do artista, que, com sua intuição aguçada, logra penetrar esta vasta escuridão, trazendo à luz, sob a forma sublime da arte, notoriamente poética, mas também pictórica, musical, alguns fragmentos das amplidões opacas ali contidas.

\footnotetext{
${ }_{38}$ Cf. M. UTSCH, Tarefas e limites da psicologia da religião..., 2013. Cf. tb. IDEM, Religião e Psicologia, 2013.

39 Cf. S. V. NOÉ, Am Anfang war das Es..., p. 182 ss.

40 Cf. R. DESCARTES, Discurso do Método, 1637.

${ }^{41}$ Pseudônimo do poeta Johann Paul Friedrich RICHTER. Cf. C. OTTO (Org.): Jean Paul: Selina oder über die Unsterblichkeit, 1827. Cf. Tb. NOVALIS, Fragmentos de Novalis, 1993.

42 Cf. S. V. NOÉ, O inconsciente é a chave para o consciente, pp. 144-168.

43 Pseudônimo do poeta Georg Philipp Friedrich von HARDENBERG.

${ }^{4}$ Pseudônimo do poeta Johann Paul Friedrich RICHTER. CF. IDEM, Hesperus, 1795.

45 Cf. F. HÖLDERLIN, [1826]. Poemas. Trad. José Paulo Paes. São Paulo: Companhia das Letras, 1991.

46 "O sentir é tudo; nome é som e fumaça". Cf. R. OTTO, op. cit., p. 33. Ou a citação completa na versão de Agostinho d'Ornellas: "Com esse sentimento o peito inunda e quando nele imersa te sentires, o nome então Ihe dá que mais quizeres: Delícia, coração, ou Divindade. Nome não acho, o sentimento é tudo, o nome é rumor vão, o nome é fumo, que o brilho dos ceus tolda e offusca!" J. W. von GOETHE, Fausto, 1867.
} 
Quanto mais fundo explora estas camadas subterrâneas à consciência, tanto mais este gênio romântico mergulha na tragicidade da existência humana, marcada pela solidão e pelo desamparo (a qual S. FREUD essencialmente designou como sendo o sentimento de desamparo - "Hilflosigkeit"47) e da sensação de impossibilidade de reconciliação consigo mesmo, com os outros, com o mundo e com Deus; e, no limite, com a descoberta de que não conhece a si mesmo, não sabe o destino para o qual é impiedosamente empurrado e que é governado por forças, que não sabe e nem é capaz de orientar para uma direção mais apropriada. $O$ ser humano é revelado na arte romântica como um estrangeiro em seu próprio país, um alienado de si mesmo, até os limites do ser. $\mathrm{E}$ os versos fruem deste amargor, transformando o lúgubre em alento, a desolação em conforto:

Temos olhos que a noite abriu em nosso interior, mais divinos que aquelas estrelas brilhantes. Sua visão alcança além dos incontáveis hóspedes mais pálidos da noite. Sem auxílio da luz eles penetram as profundezas que abrangem as regiões elevadas com inefável delícia. Glória à rainha do mundo, à grande profetisa dos mundos mais sagrados, à mãe cuidadosa do delicioso amor! Ela mandou-te a mim, tu a mais suavemente amada, sol gracioso da Noite. Agora desperto, pois sou teu e meu. Fizeste-me conhecer a Noite, entregaste-a a mim para que se tornasse minha vida; tu fizeste de mim um homem. Consumas meu corpo com o ardor de Minh' alma, de modo que eu, tornado ar purificado, possa misturar-me completamente contigo, e assim, nossa noite de núpcias durará eternamente. ${ }^{48}$

Tem-se a robusta impressão de que o gênio Romântico não se aventura por estas paragens profundas, para então trazê-las à luz, à consciência racional; mas que, quanto mais este se demora nestas recônditas paisagens da alma, mais deleite e fascínio lhe sobrevêm, de modo a cada vez mais querer demorar-se nelas. Ali ele encontra o verdadeiro ser do ser humano, que é um ser para a morte e aprende, ao invés de angustiar-se em relação à mesma, a considerá-la como uma companheira de jornada e até conselheira. Os seres mitológicos que povoam este universo interior já não precisam mais ser escondidos, alijados da vida, com salvoconduto apenas para manifestarem-se através dos sonhos, da loucura e das crenças religiosas; mas, através da genialidade do artista romântico, podem acompanhar a vida do ser humano e servir de fonte de inspiração e de busca pelo sublime, maravilhoso e fantástico inerente à sua alma. Através desta enteléquia, pois, se fundem o sensus numinis e a estética, ainda que, com certo grau de morbidez.

Para além de uma crítica ao Racionalismo, esta fase de desenvolvimento do espírito humano, conhecida através do Romantismo, não representa tão somente uma antítese àquele, mas inverte a própria posicionalidade da mesma, colocando-a no lugar da própria tese, cuja antítese passa a se tornar a compreensão iluminada da alma humana. Poder-se-ia, neste sentido, falar da instauração de uma hermenêutica remitologizante, na qual o objetivo último não se resume à exploração desta vastidão interior, para então dissecá-la com as ferramentas da razão, a técnica e a ciência moderna, conforme o gênio temporão iluminista, Sigmund FREUD, posteriormente, veio a preconizar.

Preocupa-se, muito mais, em encontrar a linguagem adequada para adentrar este mundo e permitir que outras pessoas, somente parca- e debilmente participantes da genialidade inerente ao artista, possam dele fruir, como meio para tornarem suas vidas mais verdadeiras e autênticas. Não basta apenas descrevê-lo, fazer uma tomografia da sua existência,

47 S. FREUD, Massenpsychologie und Ichanalyse, 1922; IDEM, Die Zukunft einer IIlusion, 1927 e IDEM, Das Unbehagen in der Kultur, 1930. Cf. tb.: P. M. RODRIGUES, Religião, ciência e arte como respostas ao desamparo humano: a perspectiva de Sigmund Freud. 2009.

${ }_{48}$ Novalis (Georg Philipp Friedrich von HARDENBERG, 1772-1801), Hinos à Noite, 1998.

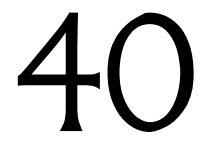


interpretá-lo com a linguagem dos conceitos, traduzi-lo; isto é, convertê-lo de sua natureza mitológica em noções formais, para então descrever a sua função e o seu destino. Ainda que isto seja possível, e até desejável, como as interpretações psicanalíticas freudianas e junguianas dos sonhos, cerca de um século mais tarde, o demonstram, sua verdadeira riqueza só será mantida, à medida que a própria linguagem coadunar com a arbitrariedade deste mundo (quase) inefável. É, pois, na arte de modo geral e na poesia, de maneira especial, que acontece esta emersão da maneira mais genuína e apropriada, trazendo à luz a pedra rara em seu estado mais radiante, natural e, por isso, bruto, para, só então, ser lapidada através da linguagem poética.

Nautas nesta vastidão interior, como Carl Gustav CARUS, procuraram, por isso, não só explorar estas riquezas profundas com as ferramentas da medicina, da psicologia, da filosofia, da literatura, mas também, dentro das suas limitações, através da arte pictórica (cf., p. ex., a obra "Heimkehr der Mönche ins Kloster"49), no seu caso, seguindo as sendas já traçadas por seu mestre Caspar David FRIEDRICH (cf., p. ex., o quadro "Der Wanderer über dem Nebelmeer ${ }^{\prime \prime 50}$ ). Certamente, já no século XX, Carl Gustav JUNG não só deu continuidade ao seu nome, à admiração a Johann Wolfgang von GOETHE e a tantas coisas mais, como também, a este caminho exploratório redescoberto51 no Romantismo, inclusive, através do auxílio de outra linguagem pictórica, como as mandalas, representadas de forma artística nos incunábulos em seu Liber novus (O livro vermelho) 52 .

Daquilo que foi dito, depreende-se que o gênio romântico, aquele carregado pelo espírito do Sturm und Drang (tempestade e ímpeto), tem por companhia de jornada, a loucura, por um lado e, por outro, o suicídio e a morte, esta muitas vezes, precoce e após intenso sofrimento sob o mal da tísica. Com isso, assinala-se a conexão entre a introspecção e a melancolia, assunto este já antecipado pela filosofia grega. 53 Quanto mais se adentra o breu no qual está envolto o próprio fundamento da vida, do ser, tanto mais se corre o risco da perda do interesse pela "insustentável leveza do ser"54. Carl Gustav CARUS descreve este percurso da alma neste processo de direcionar sua atenção à interioridade, como um gradativo apagar da luz, tal qual ocorre no lusco-fusco, portanto, correlato ao adormecimento. Os sentidos exteriores vão pouco-a-pouco perdendo sua intensidade e o sentido interior vai assumindo o controle de todas as funções do corpo humano. Neste sentido, o referido autor propõe uma espécie de círculo hermenêutico no qual o espírito humano que alcançou a autoconsciência, a partir de um estado de inconsciência originário, retorna ao mesmo, para a gradativa busca pela

49 Trad.: O retorno dos monges ao monastério.

50 Trad.: O caminhante sobre o mar de neblina.

51 "Redescoberto", pois já em Agostinho temos a referência em De Trinitate ao "logos interior", sem ignorar

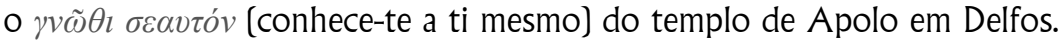

52 C. G. JUNG, O livro vermelho, 2010.

53 Este "humor melancólico" também irrompe em outros contextos histórico-culturais, p. ex., na Renascença através da arte de Albrecht Dürer ou no Barroco: “Eu, mãe de sangue denso, fardo putrefato pesando sobre a terra quero dizer quem sou, e o que por meu intermédio pode vir a ser. Sou a bílis negra, primeiro encontrada no latim, e agora no alemão, sem ter aprendido nenhum dos dois idiomas. Posso, pela loucura, escrever versos tão bons como os inspirados pelo sábio Febo, pai de todas as artes. Receio apenas que o mundo possa suspeitar de mim, como se eu pretendesse explorar o espírito do inferno. De outra forma, eu poderia anunciar, antes da hora, o que ainda não aconteceu. Enquanto isso permaneço uma poetisa, e canto minha própria história, e o que sou. Devo essa glória a um nobre sangue, e quando o espírito celeste em mim se move, inflamo rapidamente os corações, como uma deusa. Eles ficam então fora de si, e procuram um caminho mais que terrestre. Se alguém viu alguma coisa atrás das sibilas, isso aconteceu graças a mim. A. TSCHERNING [1655], Melancholey Redet selber, p. 170.

${ }^{54}$ Cf. M. KUNDERA, A insustentável leveza do ser, 1983. 
plena satisfação de sua necessidade autocompreensiva e regenerativa de sua saúde emocional e física. 55

\subsection{O sentimento como hipótese hermenêutica demitologizante}

Da já clássica distinção do conceito das atitudes humanas sob três fulcros, a cognição, a conação e a afecção, possivelmente esta última deva ser considerada como aquela que desencadeou uma ampla plataforma de pesquisa genuína para uma hermenêutica do mistério religioso. É no sentimento (Gefühl) que repousa a força e a vitalidade da religião e sob o qual, nas palavras de Julia KRISTEVA "escondem-se o sofrimento do discurso religioso e do racionalismo, este ou aquele mal-estar ou inquietação, mais estritamente pessoais". 56 É este o arcano no qual habitam os "fantasmas"57 mais recônditos da alma humana: "(...) os fantasmas são discursos de amor para um outro impossível - sempre insatisfatório, fugaz, incapaz de preencher minhas demandas ou meus desejos." 58

A maestria que a psicanálise nos ensina, notadamente através de seu célebre fundador, é metamorfosear estes sentimentos em linguagem, em um discurso, em uma narrativa, a partir do seu método precípuo de transferência e contratransferência dos mesmos à função de pai amoroso exercida pelo analista. Deste modo, "ao desnudar para meu analista as demandas e os desejos que me atravessam que eu os faço alcançar a potência da palavra e introduzo da mesma feita, essa palavra em todos os vãos reputados inomináveis da significância. Eu alcanço, assim, os meus sintomas, orquestro ou apago com maior ou menor habilidade meus fantasmas." 59 A já referida autora resume este processo da seguinte maneira: "Eu os levo, pois, a sério, mas referindo-os ao passado e, sobretudo, ao fazê-los reviver na cura, os queimo. Eles não vão desaparecer por causa disso; vão no máximo assumir uma nova configuração, mais benéfica, esperamos, para o sujeito e seus circunstantes".60

Esta função "terapêutica" lembra justamente àquilo que é intentando por muitas religiões, notadamente pelo cristianismo, pois, "por insistir nessa função paternal, o cristianismo conduz à formulação pré-consciente dos fantasmas essenciais, que margeiam os desejos dos homens (sic!]"6l, por exemplo, através de seu credo: "[p]ara o analista, entretanto, as representações sobre as quais assenta o Credo daquele que ora são fantasmas que revelam desejos ou traumatismos essenciais, e em hipótese alguma dogmas".62

Em outras palavras, neste sentido, tanto a hermenêutica psicanalítica, quanto a religiosa, ao mergulharem nas profundezas envoltas pelo nimbo do mistério e que se assentam sobre o soalho da alma humana, seguem uma mesma lei áurea, qual seja, a de modelar através da palavra, da linguagem, estes conteúdos inconscientes ou pré-conscientes de modo que aquilo

\footnotetext{
55 "Sim, quando então se nos torna evidente, que tudo aquilo que denominamos de ciência da alma consciente, se resume a uma investigação e a uma busca das condições e das leis, responsáveis pela regência inconsciente contínua da diversidade do que é vivo, ao redor e dentro de nós, dos astros às células sanguíneas, então surge em nós um círculo próprio do mundo das ideias, o qual se desenvolve a partir do estado inconsciente em direção ao consciente e, enquanto tal, novamente busca da forma mais prioritária o inconsciente e que somente se satisfará por uma possível compreensão do mesmo." C. G. CARUS, Psyche, p. 13.

56 J. KRISTEVA, No princípio era o amor: psicanálise e fé, p. $7 \mathrm{~s}$.

57 Note-se que estes "fantasmas" possivelmente se referem às fantasias freudianas, idiossincraticamente compreendidas como phantômes por J. LACAN.

58 J. KRISTEVA, No princípio era o amor: psicanálise e fé, p. 17.

59 J. KRISTEVA, No princípio era o amor: psicanálise e fé, p. 17.

60 J. KRISTEVA, No princípio era o amor: psicanálise e fé, p. 17.

61 J. KRISTEVA, No princípio era o amor: psicanálise e fé, p. 55.

62 J. KRISTEVA, No princípio era o amor: psicanálise e fé, p. 60
} 
que ora era isso seja metamorfoseado em ego. Dito de outra maneira, como o didáscalo vienense nos ensina, através da expressão sob a forma de linguagem inteligível, é que o inconsciente se torna consciente e, com isso, parte do assombro que lhe é característico, perde seu poder terrificante. Deste modo, esta arqueologia do mistério da alma humana supõe um ser com demandas anterior à linguagem. A linguagem é um recurso para categorizar, ordenar, modelar, em uma palavra, racionalizar, essas necessidades pré-existentes, dando-lhes um destino compreensível e, com isso, solapando-lhes o seu poder, por vezes, arrasador, já que sua origem, quiçá na maior parte das vezes, se fundamenta na destrudo e não no eros.

Mas e se o próprio material psíquico, bem como, sua própria função já não representa nada mais que um reflexo, um eco, um ressonar da própria linguagem? Isto é, e se a cultura, notadamente através da linguagem, é que tenha sido aquela que previamente modelou a psique humana tal qual essa ora se apresenta, com suas respectivas angústias e tentativas mais ou menos adequadas para lidar com elas? Ou seja, dito de forma cabal, que na verdade os "fantasmas" que pululam em nosso imo, nada mais seriam do que reflexos da cultura na qual somos inseridos, e, por sua vez, introjetados e apropriados através da linguagem. Ou ainda, se aquilo que nela se apresenta é tão somente linguagem e nada mais que linguagem e, com ela, o mundo que ela representa? Esta ao menos parece ser a indicação de Hans-Georg GADAMER, a partir da referência a AGOSTINHO de Martin HEIDEGGER:

Sob a palavra interior, no entanto - seja isso clareado de uma vez por todas - , não se imagina nenhum mundo privado ou psicológico anterior, que já estaria estabelecido antes da expressão verbal. Trata-se daquilo que tende a exteriorizar-se na linguagem pronunciada. A linguagem exteriorizada é a depositária de um anseio que deve ser ouvido como tal. Não existe um mundo "pré-lingúístico"', porém apenas um mundo direcionado para a linguagem, que procura expressar o pronunciável na palavra, sem que o consiga plenamente. Esta dimensão hermenêutica da linguagem é a única universal.63

Esta compreensão é singelamente desmentida pela experiência de que há angústias ubíquas, elementares (Sigmund FREUD fala em Urangst64 - "angústia primordial»), e que se apresentam, se bem que sob roupagens diversas, espraiadas por todas as culturas, não obstante, as variáveis de espaço e de tempo, e, especialmente, no que concerne a este aspecto, sob expressões idiomáticas distintas. Não o fora assim, mal se poderia falar de clássicos da literatura universal, obras primas da pintura ou escultura, imortais, ou de melhores filmes de todos os tempos. Pois que, deveras, sua universalidade é justamente assegurada por este duplo aspecto do "numinoso", que logra abalar o ser humano em sua essência, tanto no sentido de fasciná-lo quanto de assombrá-lo, ainda que se encontre isolado em meio à nação Sámi no extremo ártico ou em meio a uma metrópole qualquer, culturalmente hiperventilada. Acaso também não é ubíqua a experiência do in-die-Welt-geworfen-Sein 65 e o grito primal de angústia que se ouve desde sempre a cada criança trazida à luz? Ou, como já demarcava Wilhelm DILTHEY, no ocaso do século XIX: "[a]ssim, toda a análise do facto religião recorre a conceitos como sentimento, vontade, dependência, liberdade, motivo, que só podem ser clarificados num contexto psicológico."66

\section{A psicologia como desmistificadora do mistério}

63 Cf. J. GRONDIN, Introdução à hermenêutica filosófica, p. 21.

${ }^{64}$ Cf. Z. ROCHA, Desamparo e Metapsicologia: para situar o conceito de desamparo no contexto da metapsicologia freudiana, pp. 331-346.

65 Trad.: "Ser-jogado-no-mundo". Cf. M. HEIDEGGER, Sein und Zeit, 2006.

${ }^{66} \mathrm{Cf}$. W. DILTHEY, Ideias acerca de uma psicologia descritiva e analítica, p. 19. 
É sob esta questão crucial que se encontram Psicologia, Religião e Hermenêutica, portanto, Filosofia. É a razão, são as atitudes ou são os sentimentos que, em última análise, movem o ser humano? É a vontade67, é a busca por poder68, por sentido69 ou são suas pulsões70? Há dentro do ser humano um princípio "extrínseco", que o impele a um destino inexorável, retraído e envolto em mistério? Há motivos exteriores e interiores, inferiores e superiores, triviais e supremos? Estas são as questões basilares sobre as quais se fundam as buscas do ser humano através dos tempos e lugares nestas três áreas de exploração de sua interioridade, sob o impacto da exterioridade.

Para responder, ao menos parcialmente, estas inquirições, propomos dois caminhos que necessariamente compõem o círculo hermenêutico da ainda possível fruição do mistério hoje: por um lado, o recurso a certa psicologia, pela sua própria constituição, hermenêutica, como processo crítico e autocrítico inicial indispensável para a desmistificação do mistério, anuviado por narrativas sobre o sentir, o agir e o pensar não mais diretamente compreensíveis ao ser humano hodierno. Sob esta perspectiva também se situam o projeto de "demitologização", sob o viés teológico, de Rudolf BULTMANN71, bem como, a perspectiva do Método HistóricoCrítico, que praticamente se tornou o esteio da exegese bíblica, desde o século XIX.72 E, do ponto de vista psicológico-filosófico, o recurso à hermenêutica da suspeita, que sempre indicará para a precariedade de qualquer linguagem humana, seja ela simbólico-analítica ou racional-científica, para exprimir a vastidão interior inconsciente do ser humano.

Como vimos anteriormente, este momento pré-reflexivo, quiçá inconsciente, que resguarda os tesouros ocultos da psique humana, tão sinteticamente condensados sob a epígrafe Anschauung und Gefühti3 (intuição e sentimento) por Friedrich Daniel Ernst SCHLEIERMACHER tem um ímpeto peculiar, qual seja o de, por sua própria natureza, impelirse a vir à tona, a manifestar-se, a revelar-se. Todavia, em sua crueza, estes conteúdos podem não só ser ameaçadores, como também, e muitas vezes este é o caso, também e justamente no contexto religioso, como muitos exemplos o comprovam ao longo da história, destrutivos, aniquiladores e devastadores, do próprio sujeito e daqueles que, no caso de líderes de seitas, em um comportamento que Abraham Harold MASLOW classificara como "anaclimáxico"74, se acercam dos mesmos e são envolvidos pelos seus delírios de grandeza e fantasias apocalípticas. Por outro lado, podem, e efetivamente se manifestam fantástica-, gloriosa-, e majestaticamente, provocando justamente o efeito contrário, qual seja o de ampliar a sintonia do sujeito consigo mesmo, com os outros, com o cosmo e com o próprio Deus.

Por isso, eles, os sentimentos, os afetos, as emoções, os tesouros não lapidados, precisam encontrar vias seguras para vir à luz, para emergirem do imane oceano abissal obscuro da psique humana. A Psicanálise, bem como, outras formas psicoterápicas, dispõe para tal do ambiente protegido da práxis psicanalítica, não por acaso, mobiliada com um divã. Como nos

${ }^{67} \mathrm{Cf}$. A. SCHOPENHAUER, O mundo como vontade e representação, 1819.

68 Cf. A. ADLER, El sentido de la vida, 1933.

${ }^{69}$ Cf. V. E. FRANKL, Em busca de sentido, 1946.

70 Cf. S. FREUD [1915], Pulsões e destinos da pulsão, pp. 133-173). Note-se que a palavra alemã usada por S. Freud é Trieb, a qual remete ao campo semântico "daquilo que confere impulso a» e que, naturalmente, deve ser distinguido, como o próprio S. Freud o faz, da noção de «instinto»: "Em todo caso, ele [Freud] nunca os junta [os termos Trieb e Instinkt], nunca os opõe, ele na verdade nunca os comparou". Cf. J. LAPLANCHE, Pulsão e instinto, p. 6.

${ }^{71}$ Cf. R. K. BULTMANN, Demitologização: coletânea de ensaios, 2013.

72 Cf. E. DREWERMANN, Tiefenpsychologie und Exegese, 1992. Cf. tb. a reação crítica de G. LOHFINK, Tiefenpsychologie und keine Exegese..., 1987.

73 Cf. F. D. E. SCHLEIERMACHER, Sobre a Religião, p. 169-175 (recensão).

74 Cf. A. ÁVILA, Para conhecer a Psicologia da Religião, pp. 56, 74.

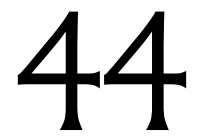


ensina Carl Gustav CARUS, a imersão neste oceano profundo inconsciente é correlata ao lusco-fusco, quando gradativamente as luzes da mente desperta e vigilante vão esvanecendo.75 Só assim as censuras, que devem ser compreendidas como reações justamente à angústia em relação ao "Leviatã»76 que domina estas paragens interiores, podem perder provisoriamente parte de seu poder repressor, sem, contudo, deixar o sujeito exposto e indefeso, e assim, ameaçado pela autodestruição.

Já a Religião, de modo geral, e o Cristianismo de modo particular, dispõem também de tal ambiente protegido, que, todavia, demasiadas vezes, por carência de compreensão da alma humana, é mal-usado e até ignorado por seus guardiões; ou seja, todos aqueles e aquelas que zelam por aquilo que classicamente era chamado de "cura d'almas». Este espaço seguro não só é dado pelas próprias Escrituras Sagradas, que segundo Eugen DREWERMANN, a partir de uma hermenêutica psicanalítica, nada mais são do que expressões da angústia humana sincrônica a todas as épocas e lugares, bem como, maneiras criativas encontradas outrora por outras pessoas, através do recurso ao simbolismo religioso, para lidar construtivamente com as mesmas.

Mas também as tradições religiosas, os credos, as liturgias, os cânticos e as orações, bem como, toda uma gama de grupos terapêuticos, que se aninham sob o seio das comunidades religiosas, assumem esta função protetora em relação às torrentes vertiginosas que por vezes irrompem, em alguns sujeitos mais e outros menos, com mais ou menos poder e intensidade, dos domínios ocultos ao estado psicossocial vigilante. $\bigcirc$ que todas estas vias de manifestação, e por que não, de revelação, têm em comum é que elas representam, tais quais as rotas dos peregrinos, uma senda segura, conhecida, livre, protegida, amparada, consolidada, ainda que muitas vezes árdua, para que os tesouros da alma humana possam aflorar, sem que se incorra o perigo da loucura, isto é, da falta absoluta de domínio sobre os mesmos.

Por outro lado, a psicologia da personalidade que se tornou ao longo dos tempos um dos troncos mais robustos da hermenêutica do mistério no contexto da Psicologia da Religião, nos indica que a experiência da angústia pode ser tipificada segundo algumas estruturas fundamentais. Fritz RIEMANN77, por exemplo, propôs que estas estruturas básicas da personalidade se constituiriam desde a mais tenra idade do infante e se manteriam relativamente estáveis ao longo de toda a vida, caracterizando maneiras fundamentais de lidar com a angústia. E que, naturalmente, as formas de enfrentamento precisam atentar a estas peculiaridades "temperamentais» para assegurar uma irrupção protegida e devidamente amparada em relação às mesmas. O seu modelo, de forma sintética, pode ser subsumido à seguinte sequência cronológica:

\subsection{O mistério revelado de forma esquizoide}

A mais remota é a estrutura de personalidade "esquizoide", que naturalmente pode se desenvolver de forma doentia em direção à esquizofrenia e, no limite, à psicose, e que se origina em uma fenda no narcisismo primário, quando o bebê não pôde experienciar, por razões essencialmente ligadas ao déficit de cuidado maternal da ou das pessoas incumbidas do suprimento desta função. Ao invés de um mundo amoroso, digno de confiança, em decorrência desta ausência ou precariedade, a criança desde cedo experimenta o mundo de modo geral como um lugar hostil e as pessoas próximas como ameaças em potencial. Ou seja, não pôde se estabelecer aquilo que na tipificação das fases do desenvolvimento proposta por

75 Cf. S. V. NOÉ, O inconsciente é a chave para o consciente..., p. 152.

76 Cf. BÍBLIA SAGRADA, O livro de Jó, capítulos $41 \mathrm{ss}$.

77 Cf. F. RIEMANN, Formas básicas de la angústia, 1978. 
Erik ERIKSON78 é denominado de "confiança básica". Ao invés disso, como reação à angústia diante da potencial frustração de que os outros e o mundo ao seu redor jamais poderão ser dignos de sua fé, a estrutura básica deste tipo de personalidade é caracterizada pela "desconfiança básica", quiçá pelo ceticismo e pela suspeita. A clássica sentença atribuída a JeanPaul SARTRE, "o inferno são os outros"79, adquire, neste contexto, uma ancoragem psíquica fundamental.

A ameaça psíquica que representa a proximidade aos outros, faz com que este tipo predominante de estrutura de personalidade se refugie, ou migrando para dentro de si, ou se afastando psíquica- e fisicamente para longe das demais pessoas. $\bigcirc$ clássico escritor alemão Hermann HESSE conhecia bem este tipo de personalidade ao escrever o seu atemporal "O lobo da estepe" 80 . Ora, este tipo certamente é o mais difícil de ser alcançado em sua profundidade, uma vez que suas raízes se encontram tão remotas, que são anteriores à formação da própria personalidade, isto é, do eu. Portanto, também carrega dentro de si um vazio tão profundo e precoce que sequer pode ser simbolizado, quiçá, vertido em palavras. Representa uma interdição fundamental da capacidade de experimentar a graça através do convívio com as demais pessoas e, portanto, o desespero de se sentir abandonado por tudo e por todos, e não por último, pelo próprio Deus, cuja representação, como outro digno de fé (confiança), jamais logrou ser elaborada.

O tipo esquizoide vive com medo da autoentrega, perda do eu e dependência. Riemann atribui essas manifestações, quando não condicionadas geneticamente, à falta de experiência de aconchego na primeira infância. A realidade envolvente, na figura da mãe, foi experimentada ou como vazia ou como ameaçadora, o que pode acontecer com crianças não-amadas ou indesejadas, mas também no caso de oferta excessiva de estímulos, por falta de estabilidade e apoio nos pais. Pessoas com essa base de experiência podem tornar-se céticas, cínicas, racionalistas. Podem ser ateias para precaver-se de possíveis decepções com Deus. Experimentam o envolvente menos como Deus pessoal e, antes, como destino inescrutável. ${ }^{81}$

\subsection{O mistério revelado de forma depressiva}

Já a segunda estrutura básica apontada por Fritz RIEMANN, cronologicamente posterior, mas ainda enredada na simbiose mãe-filho(a), conduz a uma constituição da personalidade depressiva (às vezes também bipolar, isto é, com arroubos de euforia), cujo alicerce se funda na experiência tétrica de não ter experienciado uma "maternagem" "suficientemente boa" (Donald Woods WINNICOTT82). Naturalmente, e na maioria das vezes, não por culpa da pessoa que deveria assumir esta função, mas pela própria facticidade, quando não, tragicidade, da vida e do destino, às vezes por sobrecarga dos pais, estes bebês experimentaram, em razão de uma inconstância, precariedade ou até ausência total do aconchego ao seio materno (Melanie KLEIN83), uma angústia fundamental, qual seja, a do temor profundo e desesperador de que o mundo é frio, distante e que nele não há lugar para repousar a psique alquebrada, inclusive, e justamente, entre as pessoas mais próximas. $E$ este medo do isolamento, da distância, experimentado no fundo da alma como uma ameaça terrível ao próprio ser, é

\footnotetext{
78 Cf. E. ERIKSON, O Ciclo da Vida Completo, 2004.

79 Cf. J.-P. SARTRE, Entre quatro paredes, 2005.

80 Cf. H. HESSE, O lobo da estepe, 2009.

${ }^{81}$ Cf. H. -J. FRAAS, A religiosidade humana, p. 116.

82 Cf. D. W. WINNICOTT, Os bebês e suas mães, 1988.

${ }^{83}$ Cf. M. KLEIN, A contribution to the psychogenesis of manic-depressive states, 1934.
}

\section{6}


compensado justamente pela busca de contato intenso e próximo, para não se sentir excluído, mas pertencer a um grupo.

Todavia, como há uma espécie de intuição psicológica natural às pessoas, aquelas que são procuradas pelas depressivas, se sentem esmagadas pela sua demanda emocional e, ao invés de compensar àquilo que estas tanto anseiam, isto é, o aconchego e a proximidade, acabam se afastando e se exasperando com a sua tenacidade. E seria possível traduzir esta relação quase em uma equação matemática: quanto mais aquela pessoa que quer se sentir amada e aceita procura a proximidade dos outros, tanto mais estes se sentem acuados e procuram se afastar delas, tendo por resultado, um recrudescimento ainda maior da experiência de isolamento e rejeição.

O tipo depressivo tem medo de tornar-se ele mesmo, o que percebe e teme como falta de aconchego e isolamento. Suas experiências na primeira infância concentramse na fase simbiôntica. $O$ parceiro materno é vivenciado de modo supervalorizado, quer em virtude de mimo, quer por recusa ou frustração. A tendência das mães a amimar seus pintinhos feito galinhas chocas tem um efeito inibidor sobre o desenvolvimento e não dá chances para que a criança tome iniciativas próprias. Essa atitude pode ocorrer em mães que (educando sozinhas) colocam a criança a serviço de sua autoafirmação. A experiência da recusa ou frustração corresponde à mãe frustrada que exige da criança esforços exagerados de adaptação, causando-lhe resignação. Disso pode resultar uma atitude permanente de renúncia, uma disposição para sentimentos de culpa (a criança fica devendo algo decisivo a si mesma, à sua condição de ser humano, mas os sentimentos de culpa podem ser associados com qualquer área do comportamento), que frequentemente levam a autoacusações e podem manifestar-se em exaltações religiosas. De outro lado, pode surgir um anseio místico, uma busca por ideias de redenção. A frequência de distúrbios depressivos na atualidade deve estar relacionada com a experiência muito difundida de desabrigo e desamparo cósmicos. ${ }^{84}$

Eventualmente, boa parte da demanda religiosa de modo geral e a busca pela vida religiosa, em especial, tenha o seu fulcro justamente nesta experiência de desamparo primordial, estabelecendo, como compensação de sua profunda angústia em relação ao próprio ser, enquanto indivíduo autônomo e independente, uma busca contumaz pela comunhão, pela proximidade aos outros, em grupos, comunidades e ordens religiosas. E. Drewermann vê, neste contexto, a própria psicogênese da "vocação religiosa": à custa da aceitação, do amparo e da proteção dos outros, da igreja, do estado, este tipo faz todo o possível para agradar aos outros e assim ser querido e aceito em detrimento da vivência de suas demais demandas internas de seu ser e de sua existência. Ele abre mão de si mesmo, em função de algo maior, mais poderoso, sob cujo teto espera abrigar-se das «intempéries» da vida. 85

\subsection{O mistério revelado de forma obsessivo-compulsiva}

O terceiro tipo fundamental de ancoragem psicológica da personalidade, também sequencialmente temporal em relação aos anteriores, configura uma forma de reação, quiçá desesperada, à angústia relacionada à efemeridade da vida. Encontra-se intimamente vinculado ao período da existência, onde é necessário, para o desenvolvimento psíquico e corporal como um todo, aprender àquilo que mais para o fim da vida será de valor absoluto, a reter e a largar, a segurar e a soltar. Para ir de encontro a esta angústia decorrente, em última instância,

${ }^{84}$ H.-J. FRAAS, $A$ religiosidade humana, p. 116.

85 Cf. E. DREWERMANN, Funcionários de Deus, 1994. Cf. tb. T. C. dos SANTOS, Os funcionários de Deus: a vocação religiosa a partir da psicologia profunda de Eugen Drewermann, 2010. 
da intuição antecipada da finitude e da morte, se desenvolve uma estrutura de personalidade marcada fundamentalmente por uma atitude de controle, de poder, de ordenação e de normatização, esperando lograr assim a sensação de que há coisas sólidas, incorruptíveis, resistentes ao solapar do tempo e do espaço. Este tipo talvez represente a quintessência da neurose, à medida que desenvolve uma atitude obsessivo-compulsiva, cujo reflexo provoca sofrimentos aos outros e a si mesmo.

Em termos religiosos, esta estrutura fundamental da personalidade busca encontrar quietude para a sua alma atribulada pela angústia do devir, um porto seguro, uma nave resistente às vicissitudes da vida. $E$ isso se dá através do amparo em liturgias, em rituais repetitivos, em normas que não dão margem ao acaso, em obediência e submissão à norma, à lei, à justiça divina. Acaba, destarte, desenvolvendo um movimento centrípeto, nuclear, controlado, sistematizado e estruturado, de tal sorte que o infortúnio não encontre brechas para abalar a sua existência.

O tipo compulsivo vive com medo de mudança, transitoriedade, incerteza. Isso em geral se deve a que na fase anal os impulsos da criança foram freados $\mathrm{e}$ amordaçados pela mania de ordem e super-ritualização. A compulsividade leva ao dogmatismo, legalismo, busca de ortodoxia e intolerância, mas também à superstição e magia. $O$ compulsivo é receptivo para ritos e cerimônias, não se permite ter dúvidas. Vê em Deus o vingador - uma ameaça que, por sua vez, pode compeli-lo a irrupções de blasfêmia. Neuroses eclesiogênicas (...) originam-se muitas vezes nessa área. 86

E estritamente relacionada a esta estrutura básica da personalidade fundamentada na forma de lidar com a angústia da efemeridade encontra-se a questão da culpa, do pecado, respectivamente do medo em incorrer em culpa e da respectiva atitude de vigilância e de controle para que também os outros (a família, a comunidade religiosa, a sociedade) não transgridam a ordem e assim incorram em "crime e castigo»:

O medo de culpa é um dos grandes temas da evolução. O sentido biológico está claro, a exclusão do grupo é a higiene biológica. Para nós humanos isso pode significar uma tragédia. Por natureza, nós temos o hábito de interpretar qualquer infelicidade como sendo um castigo, e mesmo a Bíblia está cheia desses esquemas. Se alguém sofre de uma doença, então é porque Deus está punindo. Não se sabe o mínimo, mas alguma coisa a gente fez de errado. Quando alguma coisa foge à regra, até hoje, isso leva muitas pessoas à justiça para serem executadas. ${ }^{87}$

\subsection{O mistério revelado de forma histérica}

E, finalmente, dentro do modelo de angústias basilares que constituem os quatro tipos de estruturas da personalidade, se encontra aquela que se exterioriza sob a forma de uma atitude histérica. A sua gênese está relacionada ao complexo de Édipo, quando, para o próprio desenvolvimento psíquico, a criança precisa minar a díade mãe-pai e se apresentar como um ator próprio, digno de atenção e interesse e capaz de reconfigurar as relações em direção ao estabelecimento de uma tríade. Por sua natureza, a inflexibilidade, a solidez, a rigidez da relação fechada pré-estabelecida pela díade mão-pai, precisa ser rompida para que um terceiro protagonista assuma o centro das «luzes da ribalta»: a(o) filha(o) querida(o), capaz de provocar,

\footnotetext{
86 H.-J. FRAAS, A religiosidade humana, 116.

87 E. DREWERMANN, Angústia e liberdade..., 2004.
} 
como fala João Guimarães ROSA88, um "redemunho" nas relações, ora despertando a atenção do pai, em detrimento da mãe e ora subvertendo a ordem pré-existe, transformando o mundo e as relações com as outras pessoas e consigo mesmo em um palco de múltiplas performances. Se a sua angústia fundamental se refere à rigidez, à imutabilidade de determinadas coisas, especialmente, em relação ao desígnio último da morte, sua atitude sintomática se exterioriza através da busca pela mudança, transformação, revolução.

Finalmente, o tipo histérico é movido pelo medo de necessidades, que ele experimenta como algo definitivo e, por conseguinte, como falta de liberdade. Suas raízes, na medida em que são condicionadas socioculturalmente, residem na falta de exemplos convincentes quanto ao papel sexual, à responsabilidade, à compreensão. $\mathrm{Na}$ idade de 4 a 6 anos ele talvez tenha estado exposto a um meio inconstante, caótico, contraditório, incompreensível e inconsequente. Esse ambiente dificulta encontrar a identidade, leva possivelmente a uma fé descompromissada, ao pragmatismo ou à piedade aparente (imitação), e torna a pessoa seduzível por promessas de salvação sem esforço, num entusiasmo que rapidamente se desvanece. ${ }^{89}$

Destarte, seguindo as consequências em relação à busca religiosa, decorrente destas quatro formas básicas da angústia e de sua indelével marca na estrutura predominante da personalidade, é possível desenhar sucintamente o seguinte quadro: "Helmut Liersch, seguindo a Riemann, pode falar de uma teologia ou religiosidade que tende ao querigmático (acentuação da separação), ao político-meditativo (acentuação da proximidade), ao cúltico- litúrgico (busca de permanência) e ao criativo (busca de liberdade)"9o.

Mutatis mutandis, a estrutura da personalidade predominantemente esquizoide tende a uma representação da imagem de Deus, enquanto "totalmente outro" ou marcada por uma «infinita diferença qualitativa» em relação ao ser humano; já em seu polo oposto, a que precisa da proximidade, se situa a estrutura essencialmente marcada pelo seu aspecto depressivo, que procura sempre reaninhar-se ao seio, agora já não mais o materno, mas o seu substituto, o social, no qual pode diluir a necessidade de formação da própria identidade, associando-se a uma mais abrangente e geral. A imagem de Deus correspondente é a do deus-irmão, do deusconosco, que carrega as dores do mundo, no convívio entre os irmãos. Talvez os exemplos clássicos deste tipo de apropriação psicológica de Deus sejam as ordens religiosas, o pietismo, a igreja das comunidades eclesiais de base. Por outro lado, a estrutura predominantemente obsessivo-compulsiva, por definição, anseia pela ordem, pelo eterno retorno do mesmo, pela segurança do perene, pela nítida distinção entre o bem e o mal, entre o certo e o errado e por uma imagem de Deus marcada essencialmente pela busca da preservação, observância, e aplicação da lei. Temos, portanto, aqui variantes diversas nas religiões que acentuam o seu aspecto legalista. $E$, finalmente, aquela estrutura predominante da personalidade que orbita em torno da cicatriz histérica, buscará o seu pendant teológico em representações sempre variáveis, dinâmicas, performáticas, que acentuam sua necessidade de mudar e de transformar criativamente o mundo; se bem que, muitas vezes, por causa de sua etiologia neurótica, tendem a ser superficiais e não logram transformações necessárias profundas.

Ou seja, cada tipo predominante busca e, às vezes, encontra aquela forma de religião correspondente à compensação de sua angústia fundamental. A consequência formal deste tipo de inquirição psicológica é se a religião, ao desempenhar este papel, isto é, aquele de corresponder a cada uma das angústias básicas, em última análise, não servirá de esteio à

88 Cf. J. G. ROSA, Grande Sertão: Veredas. São Paulo : Nova Fronteira, 2015.

89 H.-J. FRAAS, $A$ religiosidade humana, $116 \mathrm{~s}$.

90 H.J. FRAAS, A religiosidade humana, 117. 
solidificação da respectiva sintomática e, portanto, ainda que tenha o efeito de amenizar a angústia em questão, deixará incólume a origem do mal subjacente a cada tipo? Não seria justamente o cerne da cura d'almas no âmbito religioso, assim como na sua correspondente secularizada, a psicoterapia, a confrontação com as causas da dor e do sofrimento psíquico, ou seja, do mal, para que, cada qual, com a sua metodologia simbólica, possa exterminá-las, aniquilá-las, destruí-las, numa palavra, exorcizá-las?

Em outras palavras, ainda que, concordando com Hans-Jürgen FRAAS, que "[a] religiosidade segundo o tipo pode ser percebida como religião apropriada pelo indivíduo. A pergunta pela adesão a um ou outro grupo religioso ou eclesial ou escola teológica sempre é, simultaneamente, uma pergunta pela respectiva personalidade e história de vida"91, a questão fundamental que esta tipologia levanta é se a religião, a igreja, respectivamente, a terapia, no contexto secular, para justamente auxiliar o sujeito em sua contenda com a sua angústia fundamental, deverá ir ao ou de encontro às suas expectativas, que só podem ser interpretadas adequadamente como sintomáticas? E esta questão somente poderá ser respondida satisfatoriamente levando-se em conta o sofrimento específico de cada sujeito. Eventualmente, de fato, tanto a psicoterapia quanto a religião são incapazes de alcançar as razões últimas do Mal, respectivamente, do sofrimento por ele ocasionado, seja na vida individual quanto social e, portanto, precisam contentar-se em auxiliar dentro daquilo que humanamente é possível, o quê, muitas vezes, implica em nem remexer estes "fantasmas" que habitam as profundezas da alma humana. 92

\section{Conclusão: a religião como remitificação do mistério}

Ao lado do correto e necessário crivo da psicologia para desmistificar as camadas mais profundas da personalidade, com as suas angústias primordiais, essenciais e fundamentais, para que a religião não se degrade à mera compensação das mesmas, inserindo os sofrimentos pessoais e subjetivos em um contexto mais amplo de ritualização de seus sintomas, conforme a crítica tão arguta de Sigmund FREUD, que via, entre outras coisas igualmente dignas de sua repulsa, na religião, a simplória inserção da neurose individual em uma coletiva, naturalmente, revestida de certo grau de alívio aos seus praticantes, mas que não logra confrontar os mesmos com a verdadeira etiologia de suas demandas psíquicas - isto é, a única forma realmente capaz de proporcionar algum grau de enfrentamento necessário e possível dos fantasmas ali aquartelados - convém à teologia, respectivamente, à religião, o resgate de sua função outrora exercida com tanta criatividade e profunda intuição da alma humana, qual seja, a de reconstruir, dos escombros deixados para trás pela Modernidade, a sua qualidade remitologizante. Como a fênix que renasce das cinzas deixadas pela necessária, porém, terrificante, crítica da razão, ela precisa reaprender a se comunicar simbolicamente, isto é, mitologicamente, com o ser humano hodierno, para recuperar a sua vitalidade e se tornar instrumento de salvação, neste contexto, fomentar a saúde da alma.

Destarte, o recurso à religião, ou à sua forma sistematicamente elaborada, à teologia, que suporta a crítica da suspeita moderna, ao invés de reagir defensivamente, através da apologia ou polêmica, ambas como formas de se eximir de seu crivo aterrador, precisa buscar novas metáforas, parábolas, comparações, alegorias, símbolos, mitos, para expressar a verdade, com o devido vigor de outrora, sob narrativas remitificadas, capazes de enlevar o sentimento, a razão

${ }^{91}$ H.J. FRAAS, $A$ religiosidade humana, 117.

92 A propósito, Goethe cunhou uma expressão que se tornou de domínio popular e que justamente adverte sobre o perigo de cruzar esta fronteira que não tem mais retorno: "Die ich rief, die Geister werd ich nun nicht los." (Daqueles que invoquei, os espíritos, não consigo mais livrar-me). Cf. J. W. von GOETHE, O aprendiz de feiticeiro, 1797. 
e ação dos seres humanos de hoje. Pois, conforme a máxima proposta por Eugen DREWERMANN, "[s]omente um símbolo pode substituir outro símbolo".93 Sabemos, todavia, conforme intuído por Jacques LACAN94, que o único mito moderno, Totem e Tabu, devemos a Sigmund FREUD (eventualmente ignorando o "mito de Sísifo", de Albert CAMUS95 - tão emblemático para ilustrar a tragédia humana) e que, de modo geral, temos dificuldade em reativar nossas capacidades inconscientes para enfrentar simbolicamente as angústias, que se retraem às nossas capacidades de enfrentamento, reinserindo-as no plano mitológico, para ali encontrar respostas, quiçá inusitadas, para as mesmas. Em outras palavras,

[d]izer, com N. Frye, que a verdade do mito está dentro de sua estrutura é apenas dizer que tal estrutura é condição necessária, mas no âmbito do literário também suficiente, para a apresentação da verdade mítico-poética, sem que, contudo, essa verdade se dê como absoluta adequação e presença. Mais importante, porém, é uma segunda constatação: a referência à qual se dirige o mito não é idêntica, ou ao menos não se reduz ao elemento empírico-histórico-social passado ou presente, e sim o transcende. Isso equivale a dizer que, como para Schelling antes dele, o mito não é "documento" objetificável sobre os inícios "do mundo e da história", mas é "condição da consciência subjetiva que como tal quer ser levada a sério"; num certo nível crucial, o mito é "tautegórico", ou seja, fala por si mesmo e "torna-se autônomo, não podendo ser mais passível de tradução completa, como se daria no caso de uma alegoria" (KNATZ, 1989. col. 889b).96

Como, todavia, é possível, ainda hoje, após o abalo necessário e profícuo da era da razão97, recuperar aquilo que Paul RICCOEUR tão intuitivamente chamou de "segunda ingenuidade"98 ou aquilo que ele denomina de '“criações de enredo' ou 'enredamentos', e neste processo, finalmente, 'refigurações"'99? Trata-se, sem dúvida, de uma tarefa que, no contexto desta reflexão, apenas poderá ser assinalada como um trabalho em processo aberto. E especificamente, a partir daquilo que foi caracterizado aqui de "hermenêutica do mistério" como um processo que, suposto o primeiro passo inevitável da suspeita em relação à "ingenuidade" crédula originária, primeva, subjetiva, arraigada em última análise, através da linguagem, em nossa imersão no coletivo, aguenta o "exorcismo" de nossos "fantasmas" mais

\footnotetext{
93 E. DREWERMANN, Angústia e Liberdade: a ambivalência fundamental do ser humano, 2005.

${ }^{4}$ Cf. J. LACAN, Le séminaire, livre VII: l'éthique de la psychanalyse, p. 208.

95 Originalmente escrito em 1941 e publicado em 1942 em francês. Edição em português: A. CAMUS, O mito de Sísifo, 2010.
}

96 L. H. DREHER, A passagem da Exegese à Hermenêutica em sua relevância para a teoria da Literatura, p. 9.

97 Cf. neste contexto a obra de H. KÜNG: “... os teólogos começaram a levar a sério a crítica feita pela psicanálise à religião, crítica que teve em Sigmund Freud seu maior expoente, e isso em duplo sentido: desmontando as imagens falsas, regressivas e repressivas de Deus e, ao mesmo tempo, construindo imagens 'mais purificadas', 'mais libertadoras', 'com maior poder de cura'. IDEM, Freud e a questão da religião, p. 9. Cf. também o capítulo 2 da referida obra que traz o sugestivo título "[n]ão há retorno depois de Freud". IDEM, ibidem, p. 76 ss.

98 Cf. P. RICOEUR, Da Interpretação, p. 400: "O símbolo, nesse sentido, é o momento concreto dessa dialética, mas não é absolutamente seu momento imediato. (...) $\bigcirc$ concreto da linguagem de que nos avizinhamos mediante uma penosa aproximação é a segunda ingenuidade da qual sempre temos apenas um conhecimento fronteiriço, ou, antes, liminar." E também: "A reflexão volta à palavra e continua a ser reflexão, isto é, inteligência do sentido; a reflexão torna-se hermenêutica; é a única maneira pela qual ela pode tornar-se concreta e permanecer reflexão. A segunda ingenuidade não é a primeira ingenuidade; ela é pós-crítica e não pré-crítica, é uma douta ingenuidade." Apud E. GROSS, Hermenêutica e Religião a partir de Paul Ricoeur, p. $44 \mathrm{~s}$.

99 L. H. DREHER, A passagem da Exegese à Hermenêutica em sua relevância para a teoria da Literatura, p. 10. 
profundos e, aceita, não sem um quê de melancolia, que este deus que críamos encontra-se efetivamente morto.100

Que somente restaram escombros, mas que estes, por sua própria natureza e força, diria a pessoa crente, "divina", impelem à reconstrução. Somente a guisa de estímulo, e repensando a tríplice dimensão da psique humana, que a subdivide em afecções, intelecções e conações, cabe perguntar sobre os enredos possíveis para a sua remitificação. Ora, a intuição e o sentimento, como outrora também o intendiam, impulsionam àquilo que Romain ROLLAND tão poeticamente alcunhou de "sentimento oceânico" e que Sigmund FREUD101, neste contexto, seria incapaz de conceber e aceitar, porque já se trata de uma tentativa poética de remitologização. Acaso estes sonhos de imersão no todo, de reunião com a origem e o fim de tudo não embalam muitas utopias tão antigas quanto à própria história da humanidade e mantêm sua força centrípeta e conjuntiva, sob diversos enredos atuais?

E, sob o aspecto da racionalidade, acaso a própria ciência, depois de sua primeira "ingenuidade", não vem passando por um processo remitologizante, quando começa a se questionar em relação às "crenças" últimas que a fundamentam? Acaso não seria, neste sentido, plausível falar, que a Modernidade como um todo, está alicerçada sobre um mito, por sua própria natureza, refratário à análise autocrítica da ciência que lhe deu origem? Assim sendo, as recentes teorias quânticas, as narrativas acerca do bóson de Higgs, as descobertas em relação ao genoma humano, as novas "teorias de tudo", a teoria do "big bang», da "matéria escura", bem como, dos "buracos negros", os "buracos de minhoca» (cujos títulos soam como fábulas dos irmãos Grimm!) e, não por último, as expectativas associadas à neurociência, não seriam também tentativas, neste sentido, "religiosas" de remitologizar a compreensão

100 Cf. neste contexto $\mathrm{H}$. Küng: "Foram-se os tempos em que os teólogos podiam falar com ingenuidade do 'bom Deus', aquele ser tão humano, onipotente, onisciente, que controla todas as coisas. Não deveriam mais insistir sobre isso." IDEM, Freud e a questão da religião, p. 110. Naturalmente é necessário deixar em suspenso provisoriamente neste contexto a questão capital se o "Mysterium tremendum et fascinans" de R. OTTO, o qual encontramos seguramente na base do sentimento religioso, possui ou não, e em que medida, uma relação com a fonte em si do Mistério: o próprio Deus? A resposta de C. G. JUNG, neste sentido, parece articular o sentimento religioso de muitos crentes: "[e]u não preciso acreditar, eu sei." Cf. C. G. JUNG, The Face to Face Interview, p. 428. Outra forma de encarar a questão, amplamente aceita na tradição cristã, na esteira de AGOSTINHO de Hipona, entende que a "queda" do ser humano não foi total e integral, mas remanesce algo da imago dei, por exemplo, enquanto "centelha divina", no fundo de sua alma. Cf. AGOSTINHO, $A$ verdadeira religião, p. 42. Outra maneira de encarar a questão é pela via "apofática" ou "negativa": "[t]he Real (unconscious) in Lacan and God in theology both escape formalization in the same way: they are both impossible to name. In theology, this impossibility of naming God is known as apophatic or negativ theology. Both God and the unconscious are Other, escaping the subject's consciousness and conscious speech." Cf. Alexandre LEUPIN, Lacan today: psychoanalysis, science, religion, p. 115. Já no contexto da Psicologia da Religião, encontra ampla aceitação um dos princípios elementares elaborados por Théodore Flournoy, qual seja o da "exclusão de um Ser Superior"; isto é, que "os psicólogos não devem nem afirmar nem negar a existência independente do objeto religioso, um campo filosófico que é exterior ao seu campo de competência". Cf. A. ÁVILA, Para conhecer a Psicologia da Religião, p. 24. Esta nada mais é do que uma variante da "epoché", da suspensão provisória de juízo de valor, recomendada pela Fenomenologia: "Para chegar ao fenômeno puro, Husserl suspende o juízo em relação à existência do mundo exterior (transcendente). Descreve apenas o mundo como se apresenta na consciência, ou seja, reduzido à consciência. Tal suspensão ou colocação entre parênteses chamou epoqué." Cf. E. HUSSERL, $A$ crise da humanidade europeia e a filosofia, p. 8. Cf. tb. IDEM, Investigações Lógicas, 1996. Certamente a questão não pode ser decidida em si a contento, muito menos no contexto desta sumária reflexão. Todavia, fica explícita a tensão entre pontos de vista "onto-teológicos» de um lado, e «relativizantes», de outro. Talvez "o caminho do meio" mais prudente seja o de recordar que, ao final das contas, trata-se de tentativas humanas, nada mais que humanas, de dizer o indizível.

${ }_{101}$ Cf. S. FREUD, O Mal-estar na Cultura, 1930. 
acerca do ser humano, a partir de fundamentos mais palatáveis à consciência pós-moderna hodierna?

E, finalmente, sob o aspecto comportamental, acaso as novas narrativas ecológicas, as politicamente-corretas, que questionam o modelo hegemônico de globalização moderno, não são também tentativas de remitologização das crenças fundamentais que fundamentam a moral e a ética individual e coletiva (inclusive em âmbito mundial)? Em outras palavras, o espaço vazio deixado pelo ocaso das antigas narrativas, dos enredos ingênuos pré-racionais, pelo seu próprio empuxo natural, aspira por um novo preenchimento, através de novas estórias subjetivas e coletivas.

\section{Referências}

ADLER, Alfred [1933]. El sentido de la vida. Madri : Miracle, 1973. 300 pp.

AGOSTINHO. A verdadeira religião: O cuidado devido aos mortos. Trad. de N. de Assis Oliveira. São Paulo: Paulus, 2002. Coleção Patrística 19. 213 pp.

. Confissões de Santo Agostinho. 1. ed. São Paulo : Penguin, 2017. 440 pp.

ARIĖ, Philippe. O tempo da história. UNESP : São Paulo, 2013. 352 pp.

ÁVILA, Antonio. Para Conhecer a Psicologia da Religião. São Paulo : Loyola, 2007. 246 pp.

BELZEN, Jacob A. von. A Constituição histórica da Psicologia Científica da Religião. In: PASSOS, João Décio; USARSKI, Frank (Orgs.). Compêndio de ciência da religião. São Paulo : Paulus, 1013. Pp. 319-331.

Cultura, Religião e Self-Dialógico. Raízes e Caráter de uma Psicologia Cultural Secular da Religião. REVER, Belo Horizonte, pp. 30-52 (2009).

BULTMANN, Rudolf Karl [1941]. Demitologização: coletânea de ensaios. 2 a ed. São Leopoldo: EST/Sindodal, 2013. 120 pp.

CAMUS, Albert [1942], O mito de Sísifo. Rio de Janeiro : Best Seller, 2010. 140 pp.

DILTHEY, W. [1900] Die Entstehung der Hermeneutik. In: IDEM, Gesammelte Schriften, v. 5, 2. Aufl., Stuttgart : B. G. Teubner; Göttingen : Vandenhoeck \& Ruprecht, 1957, pP. 317-38.

[1883]. Einleitung in die Geisteswissenschaften. Versuch einer Grundlegung für das Studium der Gesellschaft und der Geschichte. Stuttgart : B. G. Teubner; Göttingen : Vandenhoeck\&Ruprecht, 1979. 429 pp. 2008. 129 pp. [1894]. Ideias acerca de uma psicologia descritiva e analítica. Covilhã : Lusofia press,

DREHER, Luís Henrique. A passagem da exegese à hermenêutica em sua relevância para a teoria da literatura. XI Congresso Internacional da ABRALIC: Tessituras, interações, convergências. São Paulo : USP, 13 a 17 de julho de 2008. (s/p.) 
Ciência(s) da Religião: Teoria e Pós-Graduação no Brasil. In: TEIXEIRA, Faustino (Org.). A(s) ciência(s) da religião no Brasil: afirmação de uma área acadêmica. São Paulo : Paulinas, 2001. Pp. 151-178.

DREWERMANN, Eugen. Angústia e liberdade: a ambivalência fundamental do ser humano. São Leopoldo : EST, 2005. (Palestra em DVD). . Funcionários de Deus. Lisboa : Inquérito, 1994. 416 pp. . Religião para quê?? 1a. ed. São Leopoldo : Sinodal, 2004. 156 pp. Tiefenpsychologie und Exegese. Vol. I e II. Mannheim : Patmos, 1993. 1426 pp.

ERIKSON, Erik. O Ciclo da vida completo. 1a. ed. Porto Alegre : ARTMED, 2004. 111 pp.

FRAAS, Hans-Jürgen. A Religiosidade Humana. Compêndio de Psicologia da Religião. São Leopoldo : Sinodal, 1997. 132 pp.

FRANKL, Viktor Emil [1946]. Em busca de sentido: Um psicólogo no campo de concentração. Petrópolis: Vozes, 1991. 200 pp.

FREUD, Sigmund [1930]. O Mal-estar na Cultura Porto Alegre, RS: L\&PM, 2015. 192 pp.

GADAMER, Hans-Georg, Verdade e método: Traços fundamentais de uma hermenêutica filosófica. Petrópolis : Vozes, 2008. 736 pp.

GERKIN, Charles V. The living human document: Re-visioning pastoral counseling in a hermeneutical mode. Nashville, TN : Abingdon Press, 1984. 219 pp.

GOETHE, Johann Wolfgang von [1797]. O aprendiz de feiticeiro. São Paulo : Cosac Naify, 2006. 32 pp.

GRONDIN, Jean. Introdução à hermenêutica filosófica. São Leopoldo : UNISINOS, 1999. 336 pp.

GROSS, Eduardo. Hermenêutica e Religião a partir de Paul Ricoeur NUMEN. V. 2, nº l, p. 3349. Juiz de Fora (1999).

HEIDEGGER, Martin. Ser e tempo. Petrópolis : Vozes, 2006. 598 pp.

HESSE, Hermann. O lobo da estepe. Rio de Janeiro : Best Seller, 2009. 252 pp.

HUSSERL, E. A crise da humanidade europeia e a filosofia. Introd. e trad. Urbano Zilles. 2a. ed. Porto Alegre : EDIPUCRS, 2002. 96 pp. Investigações Lógicas. 6a. Investigação. São Paulo : Nova Cultural, 1996.

JAMES, William [1902], As variedades da experiência religiosa. São Paulo : Cultrix, 2015. 488 pp. 
JUNG, Carl Gustav. Aion - estudo sobre o simbolismo do si-mesmo. Vol. 9/2 - Col. Obra Completa. 8a. ed. Petrópolis : Vozes, 2011. 384 pp.

O livro vermelho. $1^{\mathrm{a}}$ ed. Petrópolis : Vozes, 2010. 374 pp.

. The Face to Face Interview, In: C. G. JUNG Speaking: Interviews and Encounters. Princeton : Bollingen Paperbacks, 1977. 428 p.

KLEIN, Melanie (1934). A contribution to the psychogenesis of manic-depressive states. In: KLEIN, M., Contributions to psycho-analysis. London : Hogart Press, 1948. Pp. 282-310.

KUHN, Thomas S. As estruturas das revoluções científicas. São Paulo : Perspectiva, 2006. 218 pp.

KUNDERA, Milan. $A$ insustentável leveza do ser. $1^{\text {a }}$ ed. São Paulo : Record, 1983. 312 pp.

KÜNG, Hans. Freud e a questão da religião. Campinas: Verus, 2006. 152 pp.

LACAN, Jacques, Le séminaire, livre VII: l'éthique de la psychanalyse. Paris : Le Seuil, 1986. 374 pp.

LAPLANCHE, Jean. Pulsão e instinto. Percurso, v. 14, n. 27, pp. 5-13 (2001).

LESSING, Gotthold Ephraim. Über den Beweis des Geistes und der Kraft. In: IDEM, Die Erziehung des Menschengeschlechts und andere Schriften. Stuttgart : Reclam, 1965. Pp. 31 SS.

LEUPIN, Alexandre. Lacan Today: Psychoanalysis, Science, Religion. New York : Other Press, 2004. 192 pp.

LOHFINK, Gerhard, Tiefenpsychologie und keine Exegese: Eine Auseinandersetzung mit Eugen Drewermann. 2. Auflage. Stuttgart : Katholisches Bibelwerk, 1988. 112 pp.

NOÉ, Sidnei Vilmar. Am Anfang war das Es: Zur psychophilosophischen Vorgeschichte der Unterscheidung von bewusst und unbewusst vor dem Aufkommen der Tiefenpsychologie. Estudos Teológicos. São Leopoldo, v. 53 nº. 1. Pp. 178-204 (2013).

Encontros e desencontros da Psicologia com a Teologia no estudo da Religião.

Numen. Juiz de Fora, vol. 18, n. 2. Pp. 154-170 (2015).

O inconsciente é a chave para o consciente. Estudos Teológicos. São Leopoldo v. 55 n. 1 p. $144-168$ (2015).

NOVALIS [1798], Fragmentos de Novalis. Lisboa : Assírio\&Alvim, 1993. 192 pp.

OTTO, Christian (Org.). Jean Paul: Selina oder über die Unsterblichkeit. Stuttgart : Cotta'sche Verlagsbuchhandlung, 1827. $426 \mathrm{P}$. 
OTTO, Rudolf. O sagrado. aspectos irracionais na noção do divino e sua relação com o racional. Tradução de W. O. Schlupp. São Leopoldo : Sinodal/EST; Petrópolis : Vozes, 2007. 224p.

PAIVA, Geraldo, Teorias contemporâneas da Psicologia da Religião. In: PASSOS, João Décio; USARSKI, Frank (Orgs.). Compêndio de ciência da religião. São Paulo: Paulus, 1013. P. 347366.

PAUL, Jean (Johann Paul Friedrich Richter). Hesperus oder die 40 Hundsposttage. 3 vol. Berlim : 1795.

PALMER, Richard E. Hermenêutica. Lisboa: Edições 70, 2006. 284 pp.

PLATÃO, Fedro. São Paulo : Edipro, 2011. 128 pp.

RICOEUR, Paul, Da interpretação. Rio de Janeiro: Imago, 1977. 401 pp.

RIEMANN, F. Formas básicas de la angústia. Barcelona: Herder, 1978. 244 pp. Grundformen der Angst. 43. Auflage. München : Reinhard, 2017.250 pp.

ROCHA, Zeferino, Desamparo e Metapsicologia: para situar o conceito de desamparo no contexto da metapsicologia freudiana. Síntese. Belo Horizonte, v. 26, N. 86. Pp. 331-346. (1999).

ROSA, João Guimarães. Grande Sertão: Veredas. São Paulo : Nova Fronteira, 2015. 496 pp.

RÖSSLER, Dietrich, Grundriß der Praktischen Theologie. 2a ed. Berlim : W. de Gruyter, 1993. $657 \mathrm{pp}$.

SARTRE, Jean-Paul. Entre quatro paredes. $5^{a}$ ed. Rio de Janeiro : Civilização brasileira, 2005. $127 \mathrm{pp}$.

Sobre a religião. Discursos a seus menosprezadores eruditos. São Paulo: Novo Século, 2000. 176 pp.

SCHLEIERMACHER, Friedrich Daniel Ernst. Sobre a Religião: Discursos a seus menosprezadores eruditos. Recensão. NUMEN. v. 4, nº. 2, p. 169-175.

SCHOPENHAUER, Arthur [1839]. O livre arbítrio. In: Os Grandes Clássicos da Literatura. Vol. III. São Paulo : Novo Horizonte, 1982. Pp. 149-257 (2001).

SILVA, Luísa Portocarrero F. da. Da "fusão de horizontes" ao conflito de interpretações: A hermenêutica entre H.-G. Gadamer e P. Ricoeur. Revista Filosófica de Coimbra. Nº. 1. Pp. 127-153 (1992).

SOUZA, Felipe L. M. de, O livro vermelho de Jung: as polaridades da psique e as concepções de Deus. Tese de doutorado. Juiz de Fora : PPCIR, 2015. 
SPENER, Philipp Jakob. Pia desideria: oder herzliches Verlangen nach Gottgefälliger Besserung. Gießen : Brunnen-Verlag, 2005. 224 pp.

STEIN, Murray. O mapa da alma. São Paulo: Cultrix, 2006. 212 pp.

TSCHERNING, Andreas [1655]. Melancholey Redet selber. In: Walter BENJAMIN, A Origem do Drama Barroco Alemão. São Paulo : Brasiliense, 1984.

UTSCH, Michael. Religião e Psicologia. Estudos Teológicos. São Leopoldo v. 53 n. 2 p. 364-381 (2013).

Tarefas e limites da psicologia da religião: uma perspectiva dialogal. NUMEN. Juiz de Fora, v. 16, n. 2, p. 539-555 (2013).

VALÉRY, Paul. Pequena carta sobre os mitos. In: NOVAES, A. (Org.). Mutações: A invenção das crenças. Edições SESC, 2011.520 pp.

WINNICOTT, Donald Woods [1987]. Os bebês e suas mães. $4^{\mathrm{a}}$ ed.. Trad. J. L. Camargo. São Paulo : Martins Fontes, 2013. 112 pp. 